\title{
External Risk in Design-Build Projects with Fixed-Price System: The Case of DKI Jakarta Province, Indonesia
}

\author{
Lindawati $^{1 *}$, Ari Wibowo ${ }^{2}$ \\ ${ }^{1}$ National Institute of Public Administration, Jakarta, Indonesia. \\ ${ }^{2}$ Mercu Buana University, Jakarta, Indonesia. \\ * Corresponding author: \\ Email: lindafasya85@gmail.com
}

\begin{abstract}
.
The construction industry is a leading economic sector in the province of DKI Jakarta that positively contributes to its economic growth. As a province with the highest construction value in Indonesia, it used the design-build (DB) method as a project delivery system to optimise infrastructure projects. However, the DB project in DKI Jakarta had experienced some completion delays that could lead to project costs overrun. A concurrent embedded design used in this study, with quantitative as the primary approach. The data collected through interviews, documentary studies, and questionnaire surveys of 50 practitioners in the construction field. This study found that utility disruption-risk negatively affected both time and cost performance of the $D B$ projects. Meanwhile, the third-party risk did not affect the time and cost performance of $D B$ projects. Incomplete and inaccurate information regarding utility disruptions led to project completion delay and increased cost realisation compared to the initial plan. Project risk management is necessary for project performance improvement, including systematic risk identification and assessment, strategy development to prevent or avoid risk and maximise opportunities. Thus, to ensure optimal project delivery, the project owner should validate the information provided and coordinated the disruption handling before the project began.
\end{abstract}

Keywords: infrastructure construction, project performance, risk.

\section{INTRODUCTION}

The construction industry is a leading economic sector in the province of DKI Jakarta that positively contributes to its economic growth. In 2017, this sector contributed $12.81 \%$ to DKI Jakarta's Gross Regional Domestic Product (PDRB) or the third after Wholesale and Retail Trade; Car and Motorcycle Repair (16.97\%) and Processing Industry (13.44\%) [1]. In 2017, DKI Jakarta had the highest construction value and gross income compared to other regions, with a growth rate of $13.52 \%$ [2]. In this regard, the increasing demands for projects' completion certainty had encouraged the Provincial Government to carry out construction procurement with a design-build (DB) system.

However, the DB project in DKI Jakarta had experienced some completion delays. In 2015-2017, as many as 13 or $81.25 \%$ of infrastructure DB projects experienced delays that range from $4.1 \%$ to $28.8 \%$ of the initial plan. Delays in project 
completion can increase project costs, wherein a fixed price system contracts, the contractors are responsible for all risks [3].

It differs from the phenomenon in several countries where using DB models tends to increase. In Singapore, contractors assessed that DB projects performed better in quality, time, and cost than traditional projects. In the UK, project owners' satisfaction level with DB projects' performance is above average in price, time, and quality. DB projects are better in terms of timeliness and cost certainty. Likewise, in the USA, the DB project's quality, time, and cost performance were better than the design-bid-build (DBB) project [4]. Based on this description, the study aimed to reveal the external risk's effect on DB projects' performance in DKI Jakarta.

\section{METHODS}

\section{Theories and Concept}

Design-build (DB) is a method to deliver a project by contracting a single entity for design and construction services. It differs from the traditional design-bid-build (DBB) system; the owner contracts a professional to design and then contracts other entities to deliver the construction service [5]. In a DB project, the contractor is responsible for both the planning/design and construction processes. Therefore, the DB contract document would be different from the traditional method's contract [6].

In a fixed-priced system contract used in DB projects at DKI Jakarta, the work scope and the contract's total cost are fixed and bounded; contract changes do not include price adjustments. The total price can be adjusted if there is a policy stipulated by the Government. If there are additional costs for project completion, it is the contractor's responsibility [3]. Risk is an unexpected condition or event that could positively or negatively impact the achievement of project objectives [7]. Risks are associated with each project phase and must be identified to avoid adverse effects on the overall project performance. Many problems occurred in the advanced phase of the project life cycle result from risks that were not well-managed in the previous stage [8]. There are two categories of risk, namely, the internal and external threats [9]. External factors are risks that can affect project performance beyond the owner and contractors' capabilities [10].

Performance could be defined in three constraints: cost/budget, time, and quality. Successful project management has several conditions: achieving project objectives, allocated time, budgeted costs, desired performance/technology level, accepted by the customer, and effectively used resources [11]. Based on previous theory and research results, risk influences project performance, both on completion time and costs [10] [12] [13]. The delay in completing the contractor's project time means losses from the increase in overhead, material, and labor costs [12]. The analysis model to determine external risk effect on project performance are as follows. 


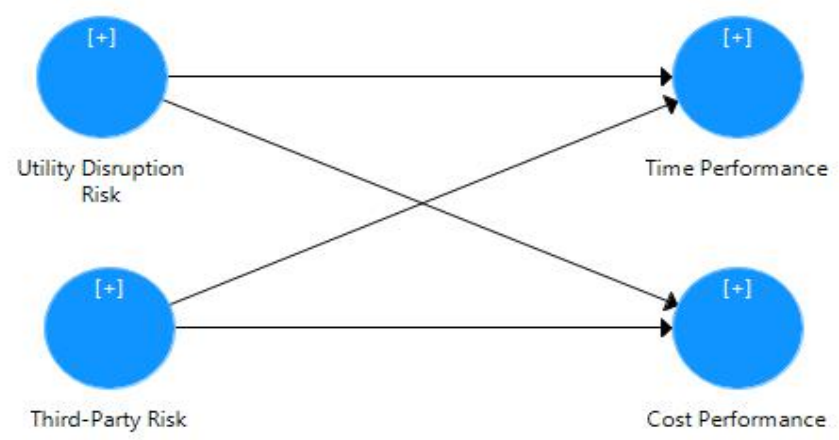

Research Hypothesis:

Fig 1. Conceptual Framework

H1: The utility disruption risk negatively affects a design-build project's time performance.

$\mathrm{H} 2$ : The utility disruption risk negatively affects a design-build project's cost performance.

H3: The third-party risk negatively affects a design-build project's time performance.

H4: The third-party risk negatively affects a design-build project's cost performance.

\section{Research Method}

This study used a mixed-method, namely concurrent embedded, with quantitative as the primary approach. This study's population were contractors involved in work with DB methods that used a fixed-price contract system in DKI Jakarta (excluding consultants and owners) in the contract period 2015-2018. The number of samples was 50 respondents, with a minimum of five years of working experience in the construction field. The questionnaires and interviews were the primary data sources, while the documentary study was the secondary. Data analyzed by using Partial Least Square (PLS).

Table 1. Research Variables and Indicators

\begin{tabular}{|c|c|c|}
\hline \multicolumn{2}{|c|}{ Variable } & Indicators \\
\hline \multirow{4}{*}{$\begin{array}{l}\text { Utililty } \\
\text { disruption } \\
\text { risk }\end{array}$} & \multirow{4}{*}{$\begin{array}{l}\text { A utility system } \\
\text { that is unknown } \\
\text { or previously } \\
\text { undetected at the } \\
\text { job site disrupts } \\
\text { the work's } \\
\text { execution [9]. }\end{array}$} & $\begin{array}{l}\text { The level of working implementation due to utility } \\
\text { disruption. }\end{array}$ \\
\hline & & $\begin{array}{l}\text { The operational level of the equipment due to utility } \\
\text { disruption. }\end{array}$ \\
\hline & & The level of material acceptance due to utility disruption. \\
\hline & & $\begin{array}{l}\text { The level of work implementation by the workforce due to } \\
\text { utility disruption }\end{array}$ \\
\hline \multirow[t]{4}{*}{$\begin{array}{l}\text { Third-party } \\
\text { risk }\end{array}$} & \multirow{4}{*}{$\begin{array}{l}\text { Change in the } \\
\text { work scope at the } \\
\text { request/demand of } \\
\text { a third-party } \\
\text { (another party } \\
\text { outside the } \\
\text { contract). }\end{array}$} & $\begin{array}{l}\text { The level of working implementation due to third-party } \\
\text { demands' fullfillment. }\end{array}$ \\
\hline & & $\begin{array}{l}\text { The operational level of the equipment due to third-party } \\
\text { demands' fullfillment. }\end{array}$ \\
\hline & & $\begin{array}{l}\text { The level of material acceptance due to third-party } \\
\text { demands' fullfillment. }\end{array}$ \\
\hline & & $\begin{array}{l}\text { The level of work implementation by the workforce due to } \\
\text { third-party demands' fullfillment. }\end{array}$ \\
\hline Time & The project & The realized time of the utilization of tools. \\
\hline
\end{tabular}

http://ijstm.inarah.co.id 


\begin{tabular}{|c|c|c|}
\hline \multicolumn{2}{|c|}{ Variable } & Indicators \\
\hline \multirow[t]{3}{*}{ Performance } & \multirow{3}{*}{$\begin{array}{l}\text { performance level } \\
\text { based on time in } \\
\text { project planning } \\
\text { and actual time } \\
{[14] \text {. }}\end{array}$} & The realized time of the completion of workers' work. \\
\hline & & $\begin{array}{l}\text { The realized time of the completion of subcontractor's } \\
\text { work. }\end{array}$ \\
\hline & & The realized time of the completion of self-managed work. \\
\hline \multirow{6}{*}{$\begin{array}{l}\text { Cost } \\
\text { Performance }\end{array}$} & \multirow{6}{*}{$\begin{array}{l}\text { The project } \\
\text { performance level } \\
\text { based on costs in } \\
\text { project planning } \\
\text { with actual costs } \\
{[15] \text {. }}\end{array}$} & The realized of materials' cost. \\
\hline & & The realized of equipments' cost. \\
\hline & & The realized of labors' cost. \\
\hline & & The realized of subcontractor's cost. \\
\hline & & The realized of personnels' cost. \\
\hline & & The realized of general cost. \\
\hline
\end{tabular}

\section{RESULT AND DISCUSSION}

\section{Outer model evaluation}

The construct unidimensionality tested by examining each construct indicator's convergent validity; requiring an external loading value of 0.5 or higher, is considered acceptable [16]. Based on these criteria, all constructs' loading factor values were higher than 0.50 . Thus, all indicators had fulfilled the validity standards.

The value of Cronbach's Alpha and Composite Reliability for each variable is above 0.80 , which meant that each construct was reliable. All indicators have a more significant correlation value with the construct than the correlation value with other constructs, so the whole construct had good discriminant validity.

\section{Inner model evaluation}

The R Square value for time performance was 0.121 . It meant that the utility disruption and third-party risk contributed $12.1 \%$ to the time performance. The utility disruption risk had a weak effect size (0.093), while third-party risk (0.001) categorized as did not affect.

Cost performance's R Square value was 0.338 . It meant that the utility disruption and third-party risk contributed $33.8 \%$ to the time performance. The utility disruption risk had a moderate effect size (0.220), while third-party risk's effect (0.048) was weak.

\section{Hypothesis test result}

The utility disruption risk (-0.334) significantly affected time performance (sig. $0.044)$, whereas the effect of third-party risk (-0.025) was insignificant (sig. 0.898). Utility disruption risk (-0.446) also significantly affect cost performance (sig. 0.000), while third-party risk $(-0.208)$ was insignificant (sig. 0.898). Thus, it concluded that two research hypotheses were accepted. The utility disruption risk negatively affected the time performance (H I) and cost performance (H II) of DB projects. 


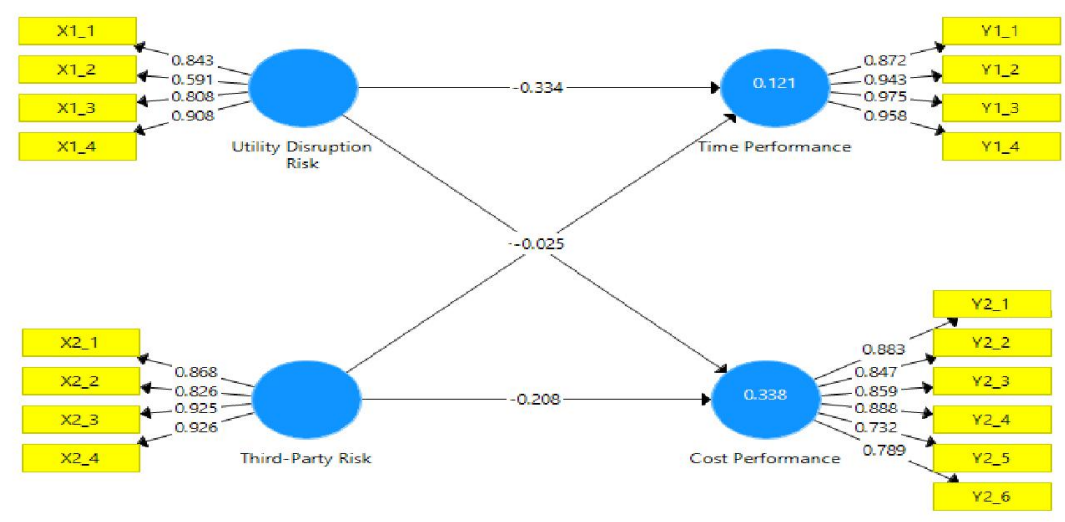

Figure 2. Outer loading

\section{Discussion}

Generally, a utility is the owners' responsibility in terms of procurement, operation, and maintenance. Likewise, if there is a need or necessity for the relocation or transfer of utilities, this is entirely the utility owner's responsibility. The problem that often occurs is the schedule related to utility disruption handling is not synchronized. Thus, it causes the construction work not to finish immediately and even overlaps with the utility disruption handling.

Based on the qualitative survey of the project practitioners of infrastructure construction projects in DKI Jakarta, the tender information regarding utilities that disrupted construction work was incomplete. Incomplete information regarding utility disruption occurred at various levels: (1) $2 \%$ of respondents stated there was no information; (2) $38 \%$ of respondents said that only a few pieces of information were available, and (3) $38 \%$ of respondents stated that only half of the data was available.

Likewise, the accuracy of the information conveyed regarding the type, function, and dimensions received at the tender with conditions in the field. All respondents stated that the data was inaccurate $(58 \%$ most of the information was incorrect, $28 \%$ partly was right, and only $14 \%$ said that a small portion of the information provided was correct). Based on the interviews, this information's incompleteness and inaccuracy caused by the inaccuracy of the utilities work's as-built drawings. It was possible because, after the utilities' installation, there had been changes in infrastructure work, and there was no updating to the as-built drawings (for instance, for the latest utility position, both in terms of alignment and elevation).

Furthermore, most respondents stated that the information conveyed about the relocation procedure and process was inaccurate related to the utility relocation schedule. After further coordination regarding the transfer of utilities, a realization schedule mismatch in the working field with $58 \%$ of respondents stated that this mismatch caused work delayed for one month or even more. This condition makes it 
difficult for construction operators to schedule construction work according to utility relocation.

The utility disruption caused the design and working method were unable to be implemented as the initial plan. Thus, it could cause a total design change or required material replacement by adjusting to existing conditions in the working field. Utility disruption also hampered the equipment operation, the level of material acceptance, and work completion. Utility disruptions occurred in each project, so the probability was very-high (VHI). Furthermore, the utility disruption caused an increase in the allocated costs $<25 \%$ or classified in the low impact category (LOW). Thus, the risk level of utility disruption was categorized as moderate (MOD).

Compared to the utility disruption, the third-party requests were more challenging to identify. As many as $30 \%$ of respondents stated that there was no information regarding third parties' risk, and the remaining $70 \%$ said there was incomplete information. The third-party risk often appears during working implementation after the third party sees the project's implementation. Even the owner does not know much about the third party's request so that the information submitted at the tender phase was incorrect.

The third-party requests should be fulfilled because, in the end, the request became a necessity even though it was not an operational eligibility requirement to obtain an Operational Eligibility Certification (SLO). The possibility level for thirdparty risk was very-low (VLOW) and caused an increase in the allocated costs $<25 \%$ or classified in the low impact category (LOW). Thus, the risk level of third-party risk was categorized as low (LOW). This study on a design-build construction project in DKI Jakarta showed different results from several previous research. The study by the Pennsylvania State University in collaboration with the Construction Industry Institute that conducted to 351 projects in 37 US states showed that: (1) the design method provides a $6 \%$ project cost advantage compared to traditional methods; (2) costs incurred due to job changes were reduced by $5.2 \%$ compared to DBB projects; and (3) project completion time that $33 \%$ faster than traditional methods [10]

Some of the main constraints in implementing DB projects in DKI Jakarta were external risk identifying and inaccurate information regarding external risks. Risk identification is critical in risk management. Risk cannot be managed unless it has been identified [17]. Recognizing the vital parts of the risk is the first step to successfully carrying out a risk assessment [18]. In general, the risk identification stage is to detail existing risks, then determine their significance (potential) and their causes through surveys and investigations of existing problems [19].

\section{CONCLUSION}

The utility disruption-risk negatively affected both time and cost performance of the DB projects. Meanwhile, the third-party risk did not significantly affect the time 
and cost performance of DB projects. Incomplete and inaccurate information regarding utility disruptions led to project completion delay and increased cost realisation compared to the initial plan. Furthermore, the lack of information related to the thirdparty risk made it challenging to handling. Ensuring a risk handling schedule was also essential and necessary to manage the risk.

A construction project's potential risk is relatively high comparing to other projects. In this regard, there must be different priorities for existing risk. Project risk management is necessary for project performance improvement. It consists of systematic risk identification and assessment, strategy development to prevent or avoid risk, and maximising opportunities. Thus, to ensure optimal project delivery, the government, as the project owner, needed to validate the information provided and coordinated the disruption handling before the project began.

\section{ACKNOWLEDGMENTS}

The authors are thankful to the PT Manggala Jaya Konstruksi for supporting information and all respondents for filling out questionnaires and fascinating discussions throughout this study.

\section{REFERENCES}

[1] Statistics of DKI Jakarta Province, Jakarta in Figures 2018. Jakarta: Statistics of DKI Jakarta Province, 2018.

[2] Subdirectorate of Construction Statistics, Construction Statistics 2018. Jakarta: BPSStatistics Indonesia, 2018.

[3] The Government of the Republic of Indonesia, Presidential Regulation Number 16 of 2018 on Government Procurement of Goods/Services. Jakarta: Cabinet Secretariat, 2018.

[4] F. Y. Y. Ling and E. F. K. Leong, "Performance of Design-Build Projects in Terms of Cost, Quality and Time: Views of Clients, Architects and Contractors in Singapore," The Australian Journal of Construction Economics and Building, vol. 2, no. 1, pp. 37-46, 2002.

[5] C. N. Juliana, A. M. Ramirez and B. J. Larkin, "Construction Management/Design-Build," in Lorman Seminar, 2005.

[6] Rato, "Evaluasi Penerapan Kontrak Lump Sum dari Sudut Pandang Kontraktor pada Proyek Pembangunan Jalan Tol (Studi Kasus Proyek Pembangunan Jalan Tol SemarangBanten)," Thesis. Surakarta: Postgraduate School University of Muhammadiyah Surakarta, 2018.

[7] S. M. Seyedhoseini and M. A. Hatefi, "Two-Pillar Risk Management (TPRM): A Generic Project Risk Management Process," Transaction E: Industrial Engineering, vol. 16, no. 2, pp. 138-148, December 2009.

[8] E. Gajewska and M. Ropel, "Risk Management Practices in a Construction Project - a case study," Thesis. Goteborg: Department of Civil and Environmental Engineering Chalmers University of Technology, 2011.

[9] P. A. P. Suwandi, "Kajian Manajemen Risiko pada Proyek dengan Sistem Kontrak Lump Sum dan Sistem Kontrak Unit Price (Studi Kasus pada Proyek Jakan dan Jembatan, Gedung, Bangunan Air)," Thesis. Semarang: Postgraduate School of Diponegoro University, 2010. 
[10] T. Alam, "Identifikasi Faktor-faktor Risiko Proyek Rancang Bangun (Design and Build) pada PT. XYZ yang Berpengaruh Terhadap Kinerja Waktu," Thesis. Depok: Faculty of Engineering University of Indonesia, 2011.

[11] R. W. Prabawani, "Analisis Dampak Risiko Proyek terhadap Kinerja Proyek (Studi pada Industri Konstruksi di Jawa Tengah Periode Tahun 2001-2010)," Jurnal Bisnis Strategi, vol. 21, no. 2, pp. 79-91, Desember 2012.

[12] Sesmiwati, V. Ariani and F. Roza, "Review Penyebab Keterlambatan pada Proyek Konstruksi," in Seminar Nasional Strategi Pengembangan Insfratruktur ke-3 (SPI-3), Padang, 2017.

[13] F. Hermawan, F. Kistiani and T. D. Santoso, "Pengaruh Pembebasan Lahan terhadap Risiko Proyek Konstruksi (Studi Kasus Social Engineering Proyek Jalan Tol Ruas Semarang Bawen)," TEKNIK, vol. 32, no. 2, pp. 88-94, 2011.

[14] P. F. Kaming, F. Rahardjo and Y. G. Situmorang, "Analisis Kinerja Proyek Konstruksi," in Konferensi Nasional Teknik Sipil 4 (KoNTekS 4), Bali, 2010.

[15] H. P. Magaline, A. J. Haryono and Andi, "Survei Mengenai Biaya Overhead serta Faktor yang Mempengaruhinya," Jurnal Dimensi Pratama Teknik Sipil, vol. 4, no. 2, 2015.

[16] I. Ghozali, Structural Equation Modeling Metode Alternatif dengan Partial Least Square (PLS) Dilengkapi Software Smartpls 3.0 Xlstat2014 dan WarpPLS 4.0 Edisi 4. Semarang: Diponegoro University Publishing Agency, 2014.

[17] Project Management Institute, Practice Standard for Project Risk Management. Newtown Square: Project Management Institute, Inc., 2009.

[18] A. E. Husin, "Model Aliansi Strategis dalam Kemitraan Pemerintah dan Swasta pada Mega Proyek Infrastruktur berbasis Value Engineering untuk Meningkatkan Nilai Kelayakan Proyek," Doctoral Thesis. Depok: Faculty of Engineering University of Indonesia, 2015.

[19] C. F. Gray and E. W. Larson, Project Management: The Managerial Process, 3 ed., New York: The McGraw-Hill Companies, 2005. 